\title{
Karakteristik Ibu Hamil Dengan KEK Di Banyuwangi 2021
}

\author{
Tria Eni Rafika Devi ${ }^{a}$ \\ ${ }^{a} A K E S$ RUSTIDA Banyuwangi, Banyuwangi, Indonesia \\ Email Korespondensi: enitria136@gmail.com
}

\begin{abstract}
Introduction: One of the causes of maternal death is Chronic Energy Deficiency. Pregnant women who are at risk for chronic energy deficiency can be seen from the measurement of the upper arm circumference which is less than $23.5 \mathrm{~cm}$. Based on data from the World Health Organization (WHO) in 2016, pregnant women who suffered from CED were 629 mothers (73.2 percent) of all maternal deaths and had a risk of death 20 times greater than mothers with normal. sez in pregnant women can be caused by the characteristics of pregnant women consisting of age, education and parity. Method: This research method is descriptive, this research was conducted to determine the characteristics of age, education and parity of pregnant women with Chronic Energy Deficiency in PUSKESMAS Sumberberas Muncar Village Banyuwangi. This study uses a total sampling technique where all the data of population members are used as a sample of 30 people. The data collection technique in this study was by using secondary data through a study of documentation of medical records or registers of pregnant women who experienced (Chronic Energy Deficiency) for the period January-August 2021 at PKM Sumberberas. Results: The results of this study are the characteristics of pregnant women with the most in PUSKESMAS Sumberberas at the age of 20-35 years as many as 23 people (76.6\%), the most parity characteristics are multiparas as many as 19 people (63.3\%), the most educational characteristics in junior high school / equivalent high school as many as 27 (90\%) where age, parity and education are one of the factors that affect the incidence of CED in pregnant women. Conclusion Efforts to deal with pregnant women with sez are by providing additional food to pregnant women, providing adequate food in the household, counseling about the importance of meeting the nutritional needs of pregnancy and changing eating habits or patterns to suit the needs of the pregnant woman's body.
\end{abstract}

Keywords: characteristics, Chronic Energy Deficiency, pregnant mother

\begin{abstract}
Abstrak
Pendahuluan: Salah satu penyebab kematian Ibu yaitu Kekurangan Energi Kronik (KEK). Ibu hamil yang berisiko mengalami kekurangan energi kronis dapat dilihat dari pengukuran lingkar lengan atas (LILA) yang kurang dari $23,5 \mathrm{~cm}$. Berdasarkan data dari World Health Organization (WHO) pada tahun 2016, ibu hamil yang menderita KEK yaitu sebanyak 629 ibu ( 73,2 persen) hingga dari seluruh kematian ibu dan memiliki risiko kematian 20 kali lebih besar dari ibu dengan LILA normal. KEK pada ibu hamil bisa disebabkan karena faktor karakteristik ibu hamil yang terdiri dari usia, pendidikan dan paritasnya. Metode: Metode
\end{abstract}


penelitian ini adalah deskriptif, penelitian ini dilakukan untuk mengetahui karakteristik umur, pendidikan dan paritas ibu hamil dengan Kekurangan Energi Kronik (KEK) di PUSKESMAS Desa Sumberberas Muncar Banyuwangi. penelitian ini menggunakan teknik total sampling dimana seluruh data anggota populasi dijadikan sebagai sampel yang berjumlah 30 orang. Tehnik pengumpulan data pada penelitian ini adalah dengan cara menggunakan data sekunder melalui studi dokumentasi catatan rekam medik atau register ibu hamil yang mengalami KEK (Kekurangan Energi Kronis) periode bulan januari-agustus 2021 di PKM sumberberas. Hasil: Hasil penelitian ini yaitu karakteristik ibu hamil dengan KEK terbanyak di PUSKESMAS sumberberas pada umur 20-35 tahun sebanyak 23 orang (76,6\%), karakteristik paritas terbanyak adalah pada multipara sebanyak 19 orang $(63,3 \%)$, karakteristik pendidikan terbanyak pada SMP/SMA sederajat sebanyak 27 (90\%) dimana umur, paritas dan pendidikan merupakan salah satu faktor yang mempengaruhi kejadian KEK pada ibu hamil. Kesimpulan: Upaya penanganan untuk ibu hamil dengan KEK yaitu dengan pemberian makanan tambahan (PMT) pada ibu hamil, ketersediaan pangan yang memadai di rumah tangga, penyuluhan mengenai pentingnya memenuhi kebutuhan nutrisi kehamilan dan perubahan kebiasaan atau pola makan agar sesuai dengan kebutuhan tubuh ibu hamil.

Kata kunci: ibu hamil, karakteristik, kurang energi kronis

\section{PENDAHULUAN}

Salah satu penyebab kematian Ibu yaitu Kekurangan Energi Kronik (KEK). Peranan kecukupan gizi sangat vital, dimulai dari sejak kehamilan trimester pertama hingga seribu hari pertama kehidupan. Gizi merupakan masalah utama yang terjadi di Indonesia antara lain yaitu Anemia, Kekurangan Energi Protein (KEP), Gangguan Akibat Kekurangan Yodium (GAKY), dan Kekurangan Vitamin A (KVA). Salah satu masalah gizi pada ibu hamil yaitu Kekurangan Energi Kronik (KEK). World Health Organization (WHO) menyatakan bahwa prevalensi ibu hamil yang mengalami Kurang Energi Kronik (KEK) cenderung terjadi di negara berkembang daripada di negara maju. Salah satu masalah gizi umum pada ibu hamil di Indonesia adalah kekurangan kalori protein (Dini et al., 2021). Ibu hamil yang berisiko mengalami kekurangan energi kronis dapat dilihat dari pengukuran lingkar lengan atas (LILA) yang kurang dari 23,5 cm. Kekurangan energi kronik yaitu suatu keadaan ibu hamil yang menderita kekurangan makanan yang berlangsung lama (kronik) dengan berbagai timbulnya gangguan kesehatan pada ibu hamil. Ibu hamil yang mengalami KEK akan berdampak buruk pada dirinya maupun bayi yang dikandungnya. Kehamilan merupakan periode yang sangat menetukan kualitas manusia di masa depan. Kekurangan gizi atau kurang energi kronik (KEK) pada ibu dan bayi telah menyumbang setidaknya 3,5 juta kematian setiap tahunnya di ASIA dan menyumbang $11 \%$ dari penyakit global di dunia. Berdasarkan data dari World Health Organization (WHO) pada tahun 2016, ibu hamil yang menderita KEK yaitu sebanyak 629 ibu (73,2 persen) hingga dari seluruh kematian ibu dan memiliki risiko kematian 20 kali lebih besar dari ibu dengan LILA normal (Terjadinya et al., 2021). Begitu 
PROFESIONAL HEALTH JOURNAL

Volume 3, No.1, Desember 2021 (Hal. 9-18)

https://www.ojsstikesbanyuwangi.com/index.php/PHJ

juga data dari Global Health Obsevatory (WHO, 2016) menyatakan bahwa Hasil Survei Pemantauan Status Gizi yang dilakukan oleh Direktorat Jendral Kesehatan Masyarakat menunjukkan bahwa Indonesia memiliki prevalensi kejadian KEK pada tahun 2017 sebesar 14,8 persen (Terjadinya et al., 2021). Berdasarkan data profil kesehatan Indonesia (2018), proporsi wanita usia subur resiko KEK usia 15-19 tahun yang hamil sebanyak 38,5\% dan yang tidak hamil sebanyak 46,6\%. Pada usia 20-24 tahun adalah sebanyak $30,1 \%$ yang hamil dan yang tidak hamil sebanyak 30,6\%. Selain itu, pada usia 25-29 tahun adalah sebanyak 20,9\% yang hamil dan 19,3\% yang tidak hamil. Serta pada usia 30-34 tahun adalah sebanyak $21,4 \%$ yang hamil dan 13,6\% yang tidak hamil. Hal ini menunjukkan proporsi WUS (Wanita Usia Subur) risiko KEK mengalami peningkatan dalam kurun waktu selama 7 tahun (Husna et al., 2020). Berdasarkan data riset kesehatan dasar yang dilakukan oleh Badan Penelitian dan Pengembangan Kesehatan tahun 2017- 2018 prevalensi KEK pada ibu hamil di Indonesia sebesar 17,3 persen dan prevalensi anemia pada ibu hamil sekitar 48,9 persen (WHO, 2016). Proporsi KEK di Jawa Tengah tahun 2015 sebesar 1.836 ibu hamil (Energi et al., 2019). Berdasarkan data RISKESDAS tahun 2018 ibu hamil dengan KEK di Jawa Timur 19,59\% dan di Banyuwangi 5\%. KEK pada ibu hamil bisa disebabkan karena faktor karakteristik ibu hamil yang terdiri dari usia, tinggi badan dan berat badan. Ibu hamil yang menikah pada usia remaja cenderung beresiko untuk mengalami KEK, menurut penelitian Mulyaningrum, menunjukkan bahwa ibu hamil yang berumur kurang dari 20 tahun memiliki risiko KEK yang lebih tinggi, bahkan ibu hamil yang umurnya terlalu muda dapat meningkatkan risiko KEK secara bermakna (Energi et al., 2019). Paritas ibu yang tinggi atau terlalu sering hamil dapat menguras cadangan zat gizi tubuh, jarak kehamilan yang terlalu dekat menyebabkan ibu tidak memperoleh kesempatan untuk memperbaiki tubuh setelah melahirkan, ibu hamil yang beban kerja yang tinggi juga membutuhkan lebih banyak energi karena cadangan energinya dibagi untuk dirinya sendiri, janin dan pekerjaannya. Masalah kesehatan ibu hamil merupakan faktor yang ikut mempengaruhi rendahnya status gizi yang disebakan kemisikinan, kurangnya pendidikan, kebiasaan makan, kondisi kesehatan yang buruk yang menyebabkan resiko dan komplikasi pada ibu hamil. Pola makan yang kurang beragam, porsi makan yang kurang dan pantangan terhadap suatu makanan merupakan faktor yang berpengaruh terhadap kejadian KEK (Nadaa, 2014). Kurangnya asupan energi yang berasal dari zat gizi makro (karbohidrat, protein dan lemak) maupun zat gizi mikro terutama vitamin A, vitamin D, asam folat, zat besi, seng, kalsium dan iodium serta zat gizi mikro lain pada wanita usia subur yang berkelanjutan (remaja sampai masa kehamilan) mengakibatkan terjadinya Kurang Energi Kronik (KEK) pada masa kehamilan, yang diawali dengan kejadian 'risiko' KEK dan ditandai oleh rendahnya cadangan energi dalam jangka waktu cukup lama yang diukur dengan lingkar lengan atas LILA (Dini et al., 2021). Selain itu juga aktifitas 
PROFESIONAL HEALTH JOURNAL

Volume 3, No.1, Desember 2021 (Hal. 9-18)

https://www.ojsstikesbanyuwangi.com/index.php/PHJ

fisik, proporsi ibu hamil remaja yang menderita risiko KEK lebih banyak dijumpai pada ibu hamil remaja dengan asupan energi kurang daripada risiko kurang ibu hamil remaja dengan asupan energi cukup. kondisi sosial ekonomi yaitu rendahnya pendidikan, jarak kelahiran yang terlalu dekat menyebabkan buruknya asupan zat gizi pada ibu hamil, gravida dan pekerjaan yang berakibat terhadap pemenuhan gizi ibu hamil (Energi et al., 2019). Tingkat pendidikan yang rendah, pengetahuan ibu tentang gizi kurang dan pendapatan keluarga yang tidak memadahi juga berpengaruh dalam pemenuhan kebutuhan gizi ibu. Ibu yang belum paham tentang gizi ibu hamil, ibu yang belum mengetahui berapakah peningkatan berat badan selama hamil yang dibutuhkan, kurangnya pengetahuan ibu tentang bahaya jika kekurangan gizi pada saat hamil, ketidakmampuan keluarga dalam menyediakan makanan bergizi dan kurangnya kesadaran terhadap ibu hamil untuk mengkonsumsi makanan dengan gizi seimbang (Masturah, 2013). Selain itu beberapa faktor penyebab ibu hamil mengalami KEK diantaranya adalah tentang pola makan yang tidak teraktur dan asupan zat gizi yang kurang sangat mempengaruhi kurangnya status gizi ibu hamil, hal ini dikarenakan selain tingkat pendidikan yang rendah, pendapatan sehari-hari keluarga ibu hamil sangat kecil sehingga ibu hamil tidak mampu untuk memenuhi zat gizi dalam tubuhnya (Triwahyuningsih \& Prayugi, 2018).

Kekurangan energi kronis pada ibu hamil dapat menyebabkan risiko terjadinya anemia, pendarahan, berat badan ibu tidak bertambah secara normal, terkena penyakit infeksi, dan menjadi penyebab tidak langsung kematian ibu, sedangkan pengaruh kekurangan energi kronis terhadap proses persalinan dapat mengakibatkan persalinan sulit dan lama, persalinan prematur iminnen (PPI), pendarahan post partum, serta peningkatan tindakan sectio caesaria.

Upaya penanganan untuk ibu hamil dengan KEK yaitu dengan pemberian makanan tambahan (PMT) pada ibu hamil, ketersediaan pangan yang memadai di rumah tangga, penyuluhan mengenai pentingnya memenuhi kebutuhan nutrisi kehamilan dan perubahan kebiasaan atau pola makan agar sesuai dengan kebutuhan tubuh. Berdasarkan hasil pendataan oleh peneliti terdapat $30 \mathrm{ibu}$ hamil di PUSKESMAS Sumberberas periode januari-agustus tahun 2021 dengan ukuran LILA $20 \mathrm{~cm}$ sebanyak 3 orang, $21 \mathrm{~cm}$ sebanyak 6 orang, $22 \mathrm{~cm}$ sebanyak 14 orang dan $23 \mathrm{~cm}$ sebanyak 7 orang. Maka peneliti tertarik untuk melakukan penelitian tentang karakteristik ibu hamil dengan KEK di PUSKESMAS Sumberberas periode januari-agustus tahun 2021.

\section{METODE}

Metode pada penelitian ini adalah analisis deskriptif. Menurut Sugiyono. (2014). Metode Penelitian Pendidikan Pendekatan Kuantitatif, Kualitatif, dan R\&D. Bandung : Alfabet Sugiyono (2014 : 21) metode analisis deskriptif adalah statistik yang digunakan untuk menganalisis data dengan cara mendeskripsikan atau menggambarkan data yang telah terkumpul sebagaimana adanya tanpa bermaksud membuat 


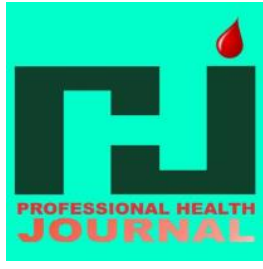

kesimpulan yang berlaku untuk umum atau generalisasi. Tujuan pada penelitian ini adalah untuk mengetahui karakteristik umur, pendidikan dan paritas ibu hamil dengan Kekurangan Energi Kronik (KEK) di PUSKESMAS Desa Sumberberas Muncar Banyuwangi periode januariagustus 2021. Variabel dalam penelitian ini adalah variable independen/bebas, dimana variable bebas dalam penelitian ini terdiri dari umur, pendidikan dan paritas ibu hamil yang mengalami Kekurangan Energi Kronis (KEK). Menurut Arikunto, 2010 Populasi adalah keseluruhan subjek penelitian (Kek et al., 2016). Populasi dalam penelitian ini adalah seluruh data ibu hamil yang mengalami Kekurangan Energi Kronis (KEK) yang berkunjung di PKM Desa Sumberberas Muncar Banyuwangi periode bulan januariagustus 2021 berjumlah 30 orang.

Dalam penelitian ini menggunakan teknik total sampling dimana seluruh data anggota populasi dijadikan sebagai sampel yang berjumlah 30 orang. Tehnik pengumpulan data pada penelitian ini adalah dengan cara menggunakan data sekunder melalui studi dokumentasi catatan rekam medik atau register ibu hamil yang mengalami KEK (Kekurangan Energi Kronis) periode bulan januari-agustus 2021 di PUSKESMAS sumberberas. Analisis data yang sudah terkumpul kemudian diolah dengan tujuan mengubah data menjadi informasi melalui tahap : penyusunan data (editing dan coding). Tempat penelitian ini di PUSKESMAS Sumberberas Banyuwangi, waktu penelitian ini dimulai pada bulan september sampai oktober 2021. Berdasarkan Surat Ijin Balasan Boleh Dialaksanakan Penelitian Di PUSKESMAS Sumberberas No 445/789/429.112.22/2021.
PROFESIONAL HEALTH JOURNAL

Volume 3, No.1, Desember 2021 (Hal. 9-18)

https://www.ojsstikesbanyuwangi.com/index.php/PHJ

\section{HASIL}

5.1 Karakteristik Ibu Hamil Kurang Energi Kronik (KEK) Berdasarkan Umur

Tabel 5.1 Distribusi Frekuensi Umur Ibu Hamil Kurang Energi Kronik di PUSKESMAS Sumberberas periode januari-agustus tahun 2021

\begin{tabular}{|c|c|c|c|}
\hline No & Umur & Frekuensi & Prosentase \\
\hline 1 & $<20$ tahun & 5 & 16,7 \\
\hline 2 & $20-35$ tahun & 23 & 76,6 \\
\hline 3 & $>35$ tahun & 2 & 6,7 \\
\hline \multicolumn{2}{|c|}{ Total } & 30 & 100 \\
\hline
\end{tabular}

5.1 Karakteristik Ibu Hamil Kurang Energi Kronik berdasarkan paritas Tabel 5.2 Distribusi Frekuensi Paritas Ibu Hamil Kurang Energi Kronik di PUSKESMAS Sumberberas periode januari-agustus tahun 2021

\begin{tabular}{|c|c|c|c|}
\hline No & Paritas & Frekuensi & Prosentase \\
\hline 1 & Primipara & 11 & 36,7 \\
\hline 2 & Multipara & 19 & 63,3 \\
\hline \multicolumn{2}{|c|}{ Total } & 30 & 100 \\
\hline
\end{tabular}

5.1 Karakteristik Ibu Hamil Kurang Energi Kronik berdasarkan pendidikan

Tabel 5.3 Distribusi Frekuensi Pendidikan Ibu Hamil Kurang Energi Kronik di PUSKESMAS Sumberberas periode januari-agustus tahun 2021

\begin{tabular}{|c|c|c|c|}
\hline No & Pendidikan & Frekuensi & $\begin{array}{c}\text { Prosent } \\
\text { ase }\end{array}$ \\
\hline 1 & SMP/SMA sederajat & 27 & 90 \\
\hline 3 & Tinggi (PT) & 3 & 10 \\
\hline \multicolumn{2}{|c|}{ Total } & 30 & 100 \\
\hline
\end{tabular}


PROFESIONAL HEALTH JOURNAL

Volume 3, No.1, Desember 2021 (Hal. 9-18)

https://www.ojsstikesbanyuwangi.com/index.php/PHJ

\section{PEMBAHASAN}

Berdasarkan tabel 5.1 umur terbanyak yang mengalami KEK pada ibu hamil di PUSKESMAS Sumberberas yaitu 20-35 tahun. Penelitian ini sesuai dengan penelitian Efrinita (2010), dengan judul hubungan antara asupan protein dengan kekurangan energi kronik (KEK) pada ibu hamil di kecamatan jebres Surakarta, bedasarkan hasil penelitian umur ibu hamil dengan KEK yang paling banyak yaitu pada umur 20-35 tahun (Kek et al., 2016) Hal ini bisa disebabkan oleh kurangnya perhatian keluarga baik suami dan orangtua dalam pendampingan pemenuhan gizi ibu hamil. Sesuai dengan hasil penelitian anna, 2018 menunjukkan bahwa dari 18 ibu hamil KEK berdasaran umur yang tertinggi adalah kelompok umur 2035 tahun sebanyak 11 orang $(61,1 \%)$ pada kelompok umur 20-35 tahun hal ini disebabkan pada umur tersebut ibu cenderung banyak beraktifitas tanpa memperhatikan asupan makanan dan kesehatan kehamilannya sehingga jatuh sakit. Peneliti menyimpulkan hasil dari data penelitian, teori dan hasil penelitian terdahulu saling berkaitan, dimana ibu hamil umur 20-35 tahun selain perlu perhatian dan dukungan keluarga tentang asupan gizinya pada umur tersebut masih sangat aktif dengan berbagai aktifitas rumahtangga dan pekerjaan lain sehingga asupan gizinya kurang. Maka asupan gizi Ibuhamil pada umur 20-30 tahun harus seimbang dengan pola aktivitasnya.

Sedangkan menurut hasil penelitian terdapat 5 orang ibu hamil KEK dengan umur kurang dari 20 tahun. Hal ini sesuai dengan penelitian Yayuk, 2019 dimana yang menikah pada usia remaja cenderung beresiko untuk mengalami KEK, hal ini menunjukkan bahwa ibu hamil yang berumur kurang dari 20 tahun memiliki risiko KEK yang lebih tinggi, bahkan ibu hamil yang umurnya terlalu muda dapat meningkatkan risiko KEK secara bermakna. Pada umur muda perlu tambahan gizi yang banyak karena selain digunakan untuk pertumbuhan dan perkembangan dirinya sendiri juga harus berbagi dengan janin yang sedang di kandung. Sedangkan umur yang tua perlu tambahan energi yang besar juga karena fungsi organ yang semakin melemah maka memerlukan tambahan energi yang cukup .

Berdasarkan tabel 5.1 jumlah ibu hamil KEK dengan umur lebih dari 35 tahun sebanyak 2 orang. Hal ini sejalan dengan penelitian husna, 2019 yaitu ibu hamil yang berumur $>35$ tahun berisiko mempunyai peluang 13,5 kali lebih besar mengalami KEK. pada umur tua diperlukan energi yang besar pula karena fungsi organ yang melemah dan diharuskan untuk bekerja maksimal, maka perlu adanya tambahan energi yang cukup sebagai pendukung kehamilan yang sedang berlangsung. Menurut peneliti pada umur lebih dari 35 tahun asupan nutrisi ibu hamil harus lebih di perhatikan dikarenakan kondidi fisik yang lebih rentan disebabkan pada usia 35 ketas adalah usia resiko tinggi.

Berdasarkan hasil penelitian pada tabel 5.2 jumlah terbanyak ibu hamil dengan KEK yaitu multipara 19 orang $(63,3 \%)$. Hal ini sejalan dengan hasil Penelitian Nugraha (2019) didapatkan bahwa ibu hamil yang multipara lebih 
PROFESIONAL HEALTH JOURNAL

Volume 3, No.1, Desember 2021 (Hal. 9-18)

https://www.ojsstikesbanyuwangi.com/index.php/PHJ

banyak dari primipara (Triwahyuningsih \& Prayugi, 2018). Sesuai dengan teori yang disebutkan netty, 2014 bahwa paritas ibu yang tinggi atau terlalu sering hamil dapat menguras cadangan zat gizi tubuh, jarak kehamilan yang terlalu dekat menyebabkan ibu tidak memperoleh kesempatan untuk memperbaiki tubuh setelah melahirkan, ibu hamil yang beban kerja yang tinggi juga membutuhkan lebih banyak energi karena cadangan energinya dibagi untuk dirinya sendiri, janin dan pekerjaannya. Kehamilan dan persalinan yang sering memiliki hubungan yang sangat erat dengan status gizi pada ibu hamil. Semakin sering seorang wanita mengalami kehamilan dan persalinan akan semakin banyak kehilangan zat besi. Semakin sering seorang wanita hamil dan melahirkan maka risiko mengalami kekurangan energi kronik akibat kekurangan gizi semakin besar karena kehamilan menguras cadangan zat besi dalam tubuh (Triwahyuningsih \& Prayugi, 2018). Kesimpulan peneliti yaitu hasil penelitian, teori dan hasil penelitian terdahulu saling berkaitan dimana dengan paritas tinggi atau lebih sering hamil dan melahirkan organ reproduksi ibu hamil lebih sering mengalami kehilangan nutrisi dan lebih besar membutuhkan asupan nutrisi untuk pemulihan kesehatan organ reproduksinya.

Pada tabel 5.2 jumlah ibu hamil KEK primipara berjumlah 11 orang $(36,7 \%)$. Hal ini juga terjadi karena ada hubungan antara pengetahuan dan pengalaman pada ibu primipara dengan kejadian Kurang Energi Kronik dimana ibu primipara pengetahuannya tentang pentingnya nutrisi saat hamil kurang serta pada ibu primipara belum mempunyai pengalaman hamil. Pengetahuan menurut Notoatmodjo (2012) merupakan hasil "tahu" dan ini terjadi setelah orang melakukan pengindraan terjadi melalui pancaindra manusia yakni : penglihatan, pendengaran, penciuman, rasa dan raba (Kek et al., 2016). Pengetahuan yang baik pada gizi seseorang membuat orang tersebut akan semakin memperhitungkan jumlah dan jenis makanan yang dipilihnya untuk dikonsumsi. Orang yang berpengetahuan gizinya rendah akan berperilaku memilih makanan yang menarik panca indra dan tidak mengadakan pilihan berdasarkan nilai gizi makanan tersebut. Sebaliknya mereka yang memiliki pengetahuan tinggi cenderung lebih banyak menggunakan pertimbangan rasional dan pengetahuan tentang nilai gizi makanan tersebut. Hal tersebut sejalan dengan penelitian Sri Handayani (2011) bahwa ada pengaruh antara pengetahuan terhadap kejadian Kurang Energi Kronik (Kek et al., 2016). Kesimpulan peneliti yaitu bahwa ibu hamil primipara belum memiliki banyak pengalaman dan kurang pengetahuan akan pentingnya zat gizi untuk janin dan dirinya sangat dipengaruhi oleh jenis makanan yang dikonsumsinya.

Berdasarkan hasil penelitian pada tabel 5.3 jumlah paling banyak dengan pendidikan rendah yaitu 27 orang (90\%). Hal ini sejalan dengan penelitian Asmaul, 2020 bahwa ibu hamil yang berpendidikan rendah mempunyai peluang 13,2 kali lebih besar mengalami KEK dibandingkan yang berpendidikan tinggi. karena dengan pengetahuan yang kurang dapat mempengaruhi ibu prilaku konsumsi dan asupan makanan sedang dengan ibu yang lulus SMA/PT cenderung tidak mengalami 
PROFESIONAL HEALTH JOURNAL

Volume 3, No.1, Desember 2021 (Hal. 9-18)

https://www.ojsstikesbanyuwangi.com/index.php/PHJ

KEK dengan tingkat pendidikan ibu yang tinggi ibu dapat mengosumsi asupan makanan yang bergizi agar dapat mencakup bagi ibu dan bayinya pendidikan formal dari ibu rumah tangga sering kali mempunyai asosiasi yang positif dengan pengembangan pola-pola konsumsi makanan dalam keluarga. Beberapa studi menunjukkan bahwa jika tingkat pendidikan dari ibu meningkat maka pengetahuan nutrisi dan praktik nutrisi bertambah baik. Usaha-usaha untuk memilih makanan yang bernilai nutrisi makin meningkat, ibu-ibu rumah tangga yang mempunyai pengetahuan nutrisi akan memilih makanan yang lebih bergizi dari pada yang kurang bergizi (Husna et al., 2020). karena ibu dengan pendidikan rendah cenderung kurang mendapatkan akses informasi dan tidak mempunyai kemampuan untuk mendapatkan pengetahuan yang lebih baik. Apabila perilaku didasari oleh pengetahuan, kesadaran dan sikap yang positif maka perilaku tersebut akan bersifat langgeng (long sting) (Sandra, 2018).

Beberapa faktor penyebab ibu hamil mengalami KEK yaitu Tingkat pendidikan yang rendah, pengetahuan ibu tentang gizi kurang dan pendapatan keluarga yang tidak memadai juga berpengaruh dalam pemenuhan kebutuhan gizi ibu. Dimana ibu yang belum paham tentang gizi ibu hamil, ibu yang belum mengetahui berapakah peningkatan berat badan selama hamil yang dibutuhkan, kurangnya pengetahuan ibu tentang bahaya jika kekurangan gizi pada saat hamil, kurangnya pengetahuan tentang gizi yang diperlukan ibu hamil, ibu hamil belum mengetahui tentang pedoman makan bagi ibu hamil (ratna, 2021). Dikarenakan selain tingkat pendidikan yang rendah, pendapatan sehari-hari keluarga ibu hamil sangat kecil sehingga ibu hamil tidak mampu untuk memenuhi zat gizi dalam tubuhnya (Triwahyuningsih \& Prayugi, 2018). Kekurangan energi kronis pada ibu hamil dapat menyebabkan risiko terjadinya anemia, pendarahan, berat badan ibu tidak bertambah secara normal, terkena penyakit infeksi, dan menjadi penyebab tidak langsung kematian ibu, sedangkan pengaruh kekurangan energi kronis terhadap proses persalinan dapat mengakibatkan persalinan sulit dan lama, persalinan prematur iminnen (PPI), pendarahan post partum, serta peningkatan tindakan sectio caesaria. Kekurangan energi kronis pada ibu hamil juga dapat menyebabkan intrauterine growth retardation (IUGR) atau bahkan intrauterine fetal death (IUFD), kelainan kongenital, anemia serta lahir dengan berat badan lahir rendah (BBLR) Bayi dengan BBLR merupakan factor risiko mengalami stunting (Utami, Setyawati, \& Ariendha, 2020).

Sedangkan jumlah ibu hamil dengan KEK yang berpendidikan tinggi hanya ada 3 orang $(10 \%)$. Pengetahuan seseorang pasti akan bertambah karena adanya faktor pendidikan yang diterima oleh responden. Pada umumnya semakin tinggi tingkat pendidikan responden akan semakin tinggi pula pengetahuan dan pemahaman responden dalam menyerap informasi baru, hal ini tergantung peda keinginan responden

untuk memahami sesuatu. Hal ini dikarenakan tingginya pendidikan seseorang maka tingkat pengetahuan yang 


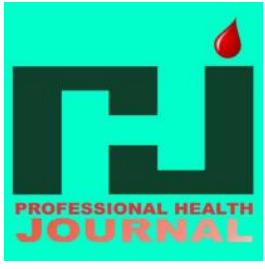

mereka dapat semakin tinggi pula dengan pendidikan tinggi maka seseorang akan cenderung mendapatkan informasi baik dari orang lain maupun media sebaliknya tingkat pendidikan yang kurang akan menghambat perkembangan dan sikap seseorang. Peneliti dapat menyimpulkan bahwa ibu hamil kekurangan energy kronis salah satunya disebabkan oleh pendidikannya yang rendah akibat pengetahuan yang kurang tentang jenis makanan, pola makan dan jenis zat gizi yang diperlukan oleh ibu hamil dan janinnya.

\section{KESIMPULAN DAN SARAN}

Karakteristik ibu hamil dengan KEK terbanyak di PUSKESMAS sumberberas yaitu pada umur 20-35 tahun sebanyak 23 orang $(76,6 \%)$. Dimana umur merupakan salah satu faktor yang mempengaruhi kejadian KEK pada ibu hamil

Karakteristik ibu hamil dengan KEK terbanyak di PKM sumberberas pada paritas multipara sebanyak 19 orang (63,3\%). Dimana paritas merupakan salah satu faktor yang mempengaruhi kejadian KEK pada ibu hamil

Karakteristik ibu hamil dengan KEK terbanyak di PKM sumberberas yaitu dengan pendidikan SMP/SMA sederajat sebanyak 27 (90\%). Dimana pendidikan merupakan salah satu faktor yang mempengaruhi kejadian KEK pada ibu hamil.

Bagi tenaga Kesehatan dan instansi Desa Sumberberas untuk dapat melakukan penyuluhan untuk ibu hamil dan masyarakat tentang pentingnya gizi pada ibu hamil untuk kesejahteraan ibu dan bayi.
PROFESIONAL HEALTH JOURNAL

Volume 3, No.1, Desember 2021 (Hal. 9-18)

https://www.ojsstikesbanyuwangi.com/index.php/PHJ
Bagi peneliti selanjutnya agar menggali lebih dalam tentang faktor-faktor yang mempengaruhi kejadian KEK pada ibu hamil.

\section{DAFTAR PUSTAKA}

Dini, M., Energi, K., \& Kek, K. (2021). Available online athttps://stikesmus.ac.id/jurnal/index. php/JKebIn/index. 12(1), 16-23.

Energi, K., Kek, K., Hamil, I. B. U., \& Wilayah, D. I. (2019). Faktor - Faktor Yang Berhubungan Dengan Kekurangan Energi Kronik (Kek) Ibu Hamil Di Wilayah Kerja Puskesmas Rowosari Semarang. Diponegoro Medical Journal (Jurnal Kedokteran Diponegoro), 8(1), 562-571.

Husna, A., Andika, F., \& Rahmi, N. (2020). Determinan Kejadian Kekurangan Energi Kronik (Kek) Pada Ibu Hamil Di Pustu Lam Hasan Kecamatan Peukan Bada Kabupaten Aceh Besar. Journal of Healthcare Technology and Medicine, 6(1), 608. https://doi.org/10.33143/jhtm.v6i1.94 4

Kek, K., Puskesmas, D. I., \& Timur, K. (2016). Karakteristik Umur dan Paritas Ibu Hamil dengan Kurang Energi Kronik ... 2016.

Masturah. (2013). Faktor-Faktor yang Mempengaruhi Status Gizi Ibu Hamil pada Masa Kehamilan yang Berkunjung ke Puskesmas Meutulang Kecamatan Panton Reu Kabupaten Aceh Barat [skripsi]. Kesehatan Masyarakat Universitas Teuku Umar, 1-55.

Sugiyono (2014 : 21). Metode Penelitian Pendidikan Pendekatan Kuantitatif, Kualitatif, dan R\&D. Bandung : 
Alfabet

Nadaa, A. (2014). Provided by Jurnal Online - Universitas Islam Kalimantan. 1(2).

Sandra, C. (2018). Penyebab Kejadian Kekurangan Energi Kronis Pada Ibu Hamil Risiko Tinggi Dan Pemanfaatan Antenatal Care Di Wilayah Kerja Puskesmas Jelbuk Jember. Jurnal Administrasi Kesehatan Indonesia, 6(2), 136. https://doi.org/10.20473/jaki.v6i2.201 8.136-142

Terjadinya, F. M., Suryani, L., Riski, M., Sari, R. G., \& Listiono, H. (2021). Jiubj 1,3,4,5. 21(1), 311-316. https://doi.org/10.33087/jiubj.v21i1.1 117

Triwahyuningsih, R. Y., \& Prayugi, A. N. (2018). Analisis Faktor-Faktor Yang Berhubungan Dengan Kejadian Kekurangan Energi Kronik (Kek) Pada Ibu Hamil. Jurnal Kebidanan, $8(2)$, 116. https://doi.org/10.33486/jk.v8i2.57

Utami, K., Setyawati, I., \& Ariendha, D. S. R. (2020). Kekurangan Energi Kronis Pada Ibu Hamil Trimester I Berdasarkan Usia Dan Graviditas. Jurnal kesehatan primer, 5(1), 1825. 